\title{
The Case of the Missing Anastasis. An iconographical conundrum in the presbytery of S. Maria Antiqua
}

\author{
Per Jonas Nordhagen and Per Olav Folgerø
}

\begin{abstract}
In the present contribution, two authors approach a limited part of the iconography in the sanctuary of Santa Maria Antiqua in Rome, painted during the pontificate of John VII (705-707 AD). Two different hypotheses will try to come closer to a solution of a problem concerning the Christ cycle on the sanctuary side walls, where Christ's appearance to the Disciples on the Road to Emmaus is the concluding motif. This rather reasonable solution stands, however, in huge contrast to John's Christ cycle in his oratory in Old Saint Peter's Basilica which concludes with the 'Harrowing of Hell' or Christ's descent into Hades. Being a novelty, this, so called Anastasis-scene, where Christ liberates the prisoners of Hades, has a strong soteriological, or salvation historical, meaning. Anastasis, which, in fact, appears in two different locations in John's rich assembly of motifs in S. Maria Antiqua, is wholly absent from the bighly 'cerebral' sanctuary iconography. Our two alternative solutions to this absence both include an Anastasis, either as a free hanging icon (Nordhagen), or as a motif included in the vast Adoration scene on the triumphal arch, here located below the Crucifixion on the steep Cliff of Golgotha (Folgero).
\end{abstract}

Among the many problems by the engendered wealth of pictures still visible in the presbytery in S. Maria Antiqua in Rome, there is one of central importance for the reconstruction of the highly charged iconographic ensemble concentrated there. ${ }^{1}$ It regards the scene with which the Christ cycle set up by John VII on the sancturary side walls was brought to its conclusion. The cycle, it should be stated, was an integral part of the manyfaceted imagery introduced by this pope into the presbytery. ${ }^{2}$ There can be no doubt as to what scene it is that brings John's Christ cycle to its close on the west (right) wall. The Disciples on the Road to Emmaus, the last of four scenes illustrating Christ's Appearances after His Death, stands as the very last panel in the lower row at the corner between this wall and the pillar which supported the great arch that opened into the nave. ${ }^{3}$ On the 'map' tracing the

\footnotetext{
${ }^{1}$ For the fresco decoration ascribed to John VII (AD 705-707) in the presbytery, see Nordhagen 1968 , 15-54.

2 Nordhagen 1968, 22-38.

${ }^{3}$ Nordhagen 1968, 38. For its place in the north-west corner, cf. also the original drawing as reproduced in Nordhagen 1968, Pl. 134, n. 12.
} 


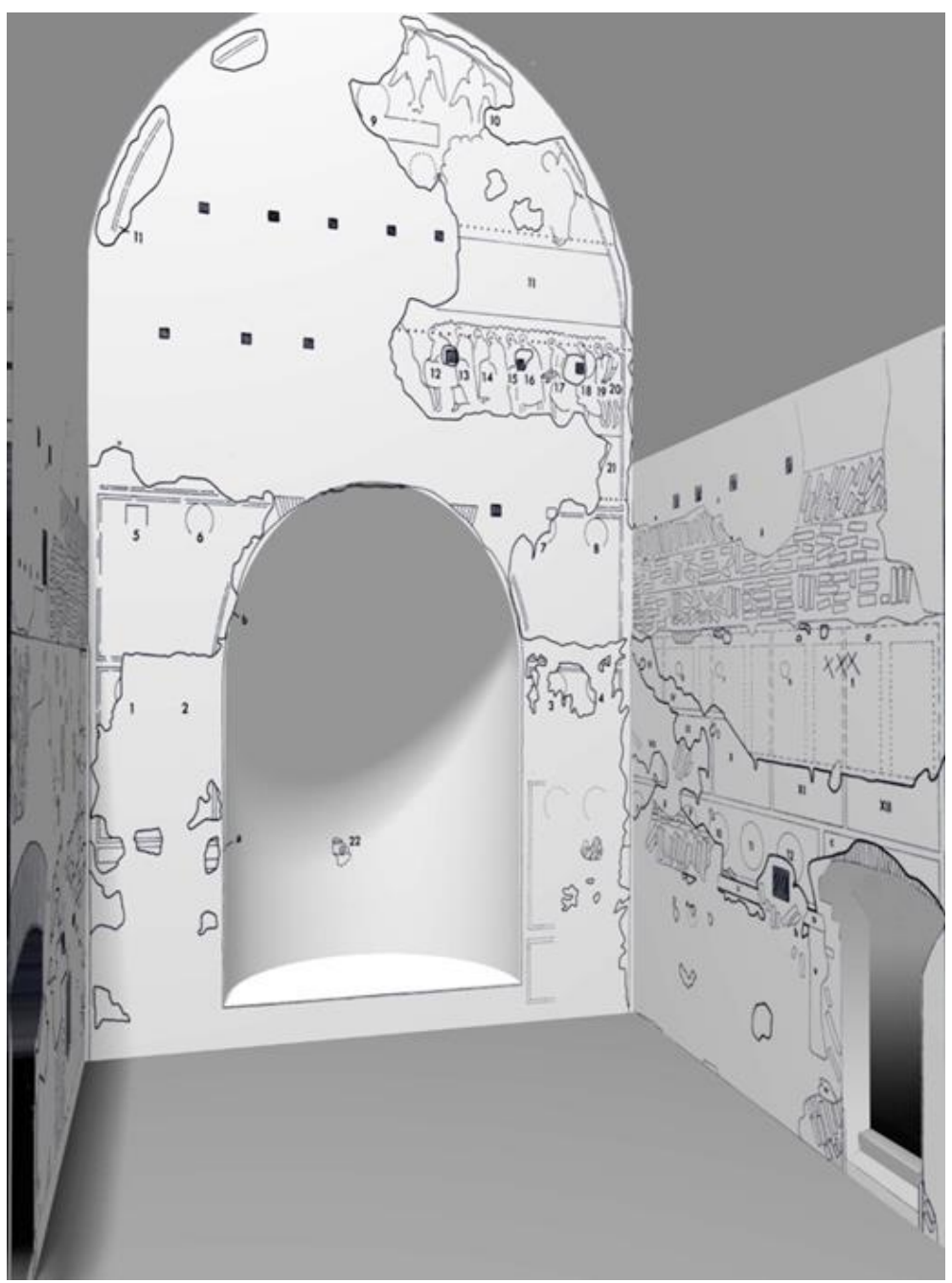

Fig. 1 Fresco decoration of John VII in the presbytery of S. Maria Antiqua. 3-dimensional digital map based on Nordhagen 1968, Pls.133-135. (C) Design A.E. Andresen.

extension of John VII's decoration in the presbytery, the number XII (lower right wall) marks the position of the Emmaus scene (Fig. 1). The identification is certain. In the panel are seen the outlines of walking figures (three) and, in the background, the inscription (ci)VITAS (emma)VS is written on the emblem of a city. ${ }^{4}$ A central episode among Christ's Appearances, the Emmaus scene would seem a well-chosen epilogue to the series.

There is, nevertheless, cause for some rethinking on this point. Pope John VII (AD 705-707) is credited with an iconographic novelty of unusual fame, the introduction into Byzantine art of the Anastasis, or 'Harrowing of Hell', the scene in which Christ, bursting into Hades, frees Adam and Eve and the other prisoners tormented there (Fig. 2). According

${ }^{4}$ Nordhagen 1968, Pls. 37, a-b and 123, 44. Identified as Emmaus in Wilpert 1917, 903; Tea 1937, 321. 


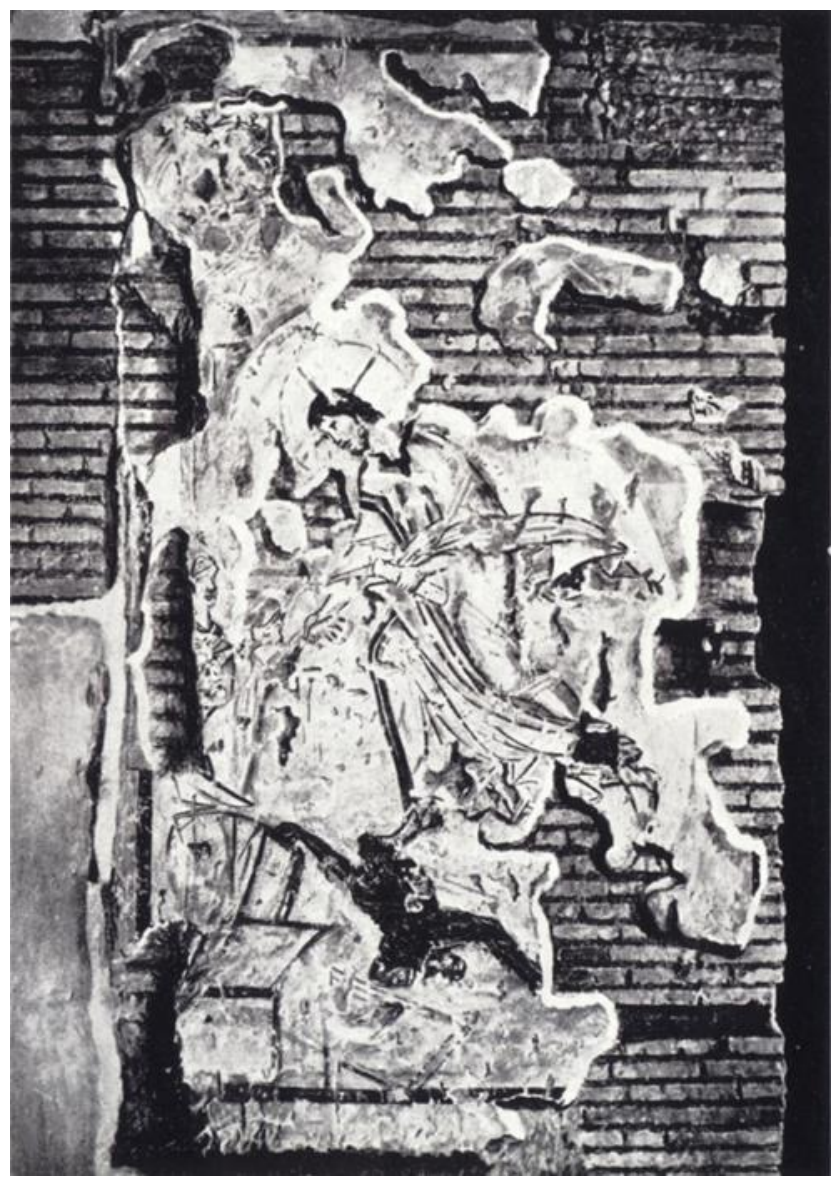

Fig. 2 The Anastasis ('Harrowing of Hell'). Fresco at doorway leading to Palatine Ramp, S. Maria Antiqua. AD 705-707. Photo: from the original watercolour for the plate in Wilpert Die römischen Mosaiken und Malereien, 1917 (C).

to André Grabar, it is in the art produced under John VII that we find the earliest known instances of this arch-Byzantine scene; ${ }^{5}$ in her seminal monograph on the Anastasis, Anna D. Kartsonis draws the same conclusion and places the creation of the image within the context of the imperial church policy at the end of the seventh century AD. ${ }^{6}$ For his part, the author of the first of the following two essays has argued that the two occurrences of the Anastasis in S. Maria Antiqua, both datable to the eighth century, are due to John VII's patronage. ${ }^{7}$ Standing near the main entrances to the church, they are here coupled with adoration pictures in which a donor approaches the Virgin; he is undoubtedly Pope John himself. ${ }^{8}$

As noted by Grabar and Kartsonis, the Anastasis picture was present also in the mosaics set up by Pope John in his oratory in the old Vatican Basilica, a decoration now lost but known to us partly from mosaic fragments taken from it when the basilica was dismantled in the early seventeenth century, and partly from a set of drawings made at the same time for the antiquarian Giacomo Grimaldi (Figs. $3 a-b) .{ }^{9}$ The Anastasis did not survive the destruction of the oratory, but its presence among the scenes of The Life of Christ in the mosaic and its place at the very end of it, are

\footnotetext{
5 Grabar [1936] 1971, 245-248; 1980, 105-106.

${ }^{6}$ Kartsonis 1986, 70-82.

${ }^{7}$ Nordhagen 1968, 81-82, 86.

8 The panel with the Anastasis, remains of which are found on the facade of the Oratory of The Forty Martyrs, at the Forum entrance to the church, is firmly linked with John VII's decoration inside the church on paleographical evidence; Nordhagen 1968: Euthymius panel, 85-86 and Pl. 124, 53. For the Euthymius panel and its lettering, see further Nordhagen 2017, 172, Fig. 23.

9 Bibliography in Nordhagen 1965,121-122. On the oratory and its decoration see now Ballardini and Pogliani 2013.
} 

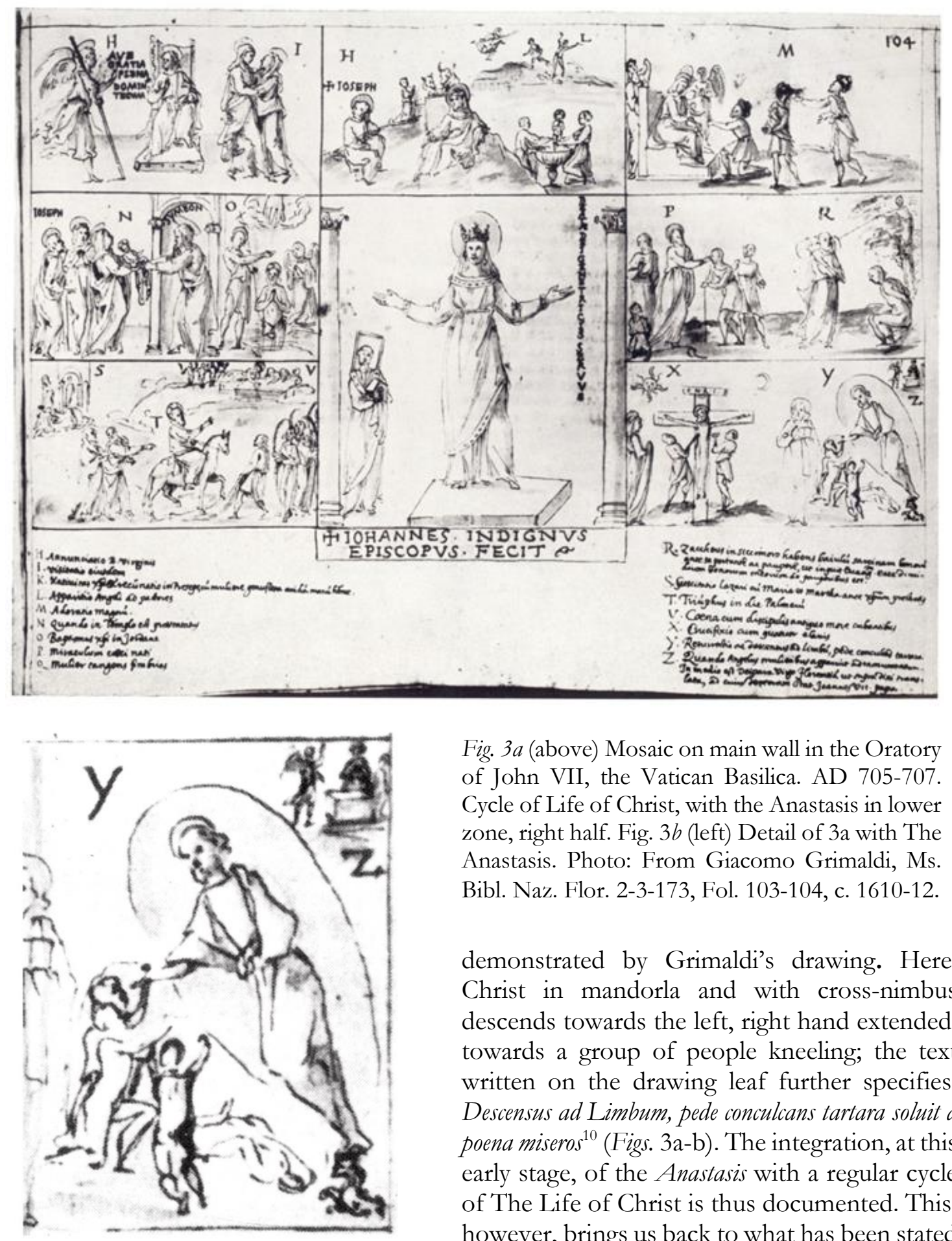

Fig. $3 a$ (above) Mosaic on main wall in the Oratory of John VII, the Vatican Basilica. AD 705-707. Cycle of Life of Christ, with the Anastasis in lower zone, right half. Fig. $3 b$ (left) Detail of $3 a$ with The Anastasis. Photo: From Giacomo Grimaldi, Ms. Bibl. Naz. Flor. 2-3-173, Fol. 103-104, c. 1610-12.

demonstrated by Grimaldi's drawing. Here, Christ in mandorla and with cross-nimbus descends towards the left, right hand extended, towards a group of people kneeling; the text written on the drawing leaf further specifies: Descensus ad Limbum, pede conculcans tartara soluit a poena miseros ${ }^{10}$ (Figs. 3a-b). The integration, at this early stage, of the Anastasis with a regular cycle of The Life of Christ is thus documented. This, however, brings us back to what has been stated

10 On Grimaldi’s drawing, Nordhagen 1965, Pl. 18. 
above, that it was the Emmaus scene which, on the west wall, marked the end of John's Christ cycle on the presbytery walls. Should not the Anastasis, a scene which brought to the cycle in the oratory an essentially sharpened eschatological import, have struck the final note also among the presbytery frescoes? Yet, as can be established with near certitude, it was not among the panels in the fresco cycle painted there. Its absence and the mystery towards which it points, are in need of further clarification.

As to where in the presbytery an eventual, now lost, Anastasis scene may have had its place, the options are, in fact, very limited. Despite their present lacunary state, John's frescoes in this part of the church can be thoroughly mapped, and they leave no room for additional panels in which this scene might have figured (cf. Fig. 1) ${ }^{11}$ Nor did the presbytery have a fourth wall where it could have been situated, since, as is shown by the architecture in the state in which it was found, it opened with the above-mentioned great arch towards the nave. No additional wall space was available in this area. Yet, almost certainly, the Anastasis, visually potent and carrying significant decretal matter, must have been present also in this part of the Forum church. The following contributions offer two alternatives for its location. The element of conjecture contained in them is obvious, given the meagre evidence on which they build. Yet the authors have thought it worthwhile to try to get to the bottom of the problems encapsulated by our 'case'.

\section{Hypothesis A: the Anastasis icon}

A representation of the Anastasis set in the apse of the church is a possibility not to be entirely ruled out. Stratigraphic data indicate that John VII's decoration included the apse, but his apsidal picture was destroyed when Pope Paul I in the mid-eighth century put up a new fresco layer there. ${ }^{12}$ True, the Anastasis, as a symbol of salvation, was depicted in the apse of the funerary chapel which the courtier Theodore Metochites set up for himself in Late Byzantine Constantinople (the Church at Chora, c. 1310-1320). ${ }^{13}$ S. Maria Antiqua, however, was not the mortuary church of John VII, who was laid to rest in his oratory in the Vatican Basilica. Yet the weightiest argument against the apsidal thesis is that it is nearly unthinkable that this fulcrum should have contained anything but an image honouring the Virgin. Given the dedication of the church to Mary, and also the Pope's intense devotion to her as his Protectress, other alternatives are unlikely. This, finally, leads to the conclusion that the Anastasis is most likely to have been present, in this vast iconographic display, in the form of a centrally placed, free-hanging icon.

Arguments which support such a thesis are based on what can be deduced from the pairs of 'twin pictures' of which we have spoken earlier, the ones placed near the main doors of the church and of which John VII was the patron. Twice repeated, they included, in addition to the Anastasis, a donor panel which held a representation of the Pope paying homage to Mary. These double images may in fact reflect, even copy, twin icons of similar motifs which were centrally positioned either on the altar or on an early form of iconostasis

\footnotetext{
${ }^{11}$ For details in the three-dimensional 'map' visualized in Fig. 2, see Nordhagen 1968, pls. 132-135.

12 Nordhagen 1968, 54.

13 Lazareff 1967, Fig. 461.
} 
in the sanctuary. ${ }^{14}$ As noted by several authors, a number of fresco panels datable to the seventh century in this church contain subject matter reappearing as cherished motifs in later icon painting, thus they may have had a function similar to what has been suggested here, having been set up to enhance and multiply the effect of real icons present in the church. Among these early 'fresco-icons' are figures of prominent Greek saints-namely, St Demetrius, ${ }^{15}$ St Barbara ${ }^{16}$ and St Panteleimon ${ }^{17}$ —but there are also figurative scenes which are the forerunners of celebrated Byzantine iconic types like the Virgin Eleousa, ${ }^{18}$ the Deesis ${ }^{19}$ and the Forty Martyrs of Sebasthe.$^{20}$ What may have escaped us is that in the Forum church these 'iconic frescoes' may have supplemented or worked in unison with real icons of identical content that were exhibited in the church; for the devout these copies will have served as votive panels of exceptional prestige. A function of a similar kind, then, is what might be ascribed to the two pairs of Anastasis-cum-Donor frescoes, which are under discussion here. Also, John VII's role as a patron of icon painting is well-documented, testified not only by the huge encaustic icon in S. Maria in Trastevere, which has been plausibly attributed to him by Carlo Bertelli, ${ }^{21}$ but also by the reference in the Liber Pontificalis to pictures set up by him in many churches, 'in which his own countenance can be seen'; no doubt these were icons. ${ }^{22}$ The idea that he had the crucial Anastasis scene set up in icon form in S. Maria Antiqua, coupled with a picture of himself in adoration of the Virgin, is thus supported not just by what can be gleaned from the stock of images available in the church. A source of unquestionable authority like the Liber Pontificalis adds credibility to this alternative.

If, as argued by Kartsonis, the Anastasis embodies some cherished dogma hammered out in this period, its message could nowhere be broadcast more effectively than in the setting here conjured up for it. As the focal point of John VII's many-faceted decoration in the presbytery, an icon depicting the Anastasis, centrally exposed, may have acted as a summa of the world of pictures that enveloped it, placed as it was as a striking counterpoint to the

14 On the iconostasis, traces of which are found in the protesis (Chapel of Theodotus) in the same church, cf. Tea 1937, 102.

${ }_{15}$ St Demetrius: Nordhagen 1978, 105, Pls. 28-29.

${ }_{16}$ St Barbara: Nordhagen 1978, 120-121, Pls. 45-48.

${ }^{17}$ St Pantaleimon: Nordhagen 1978, 126, Pls. 49, 42-43. The identification of this figure as a St

Panteleimon, even in the absence of a legend giving his name, is certain: a young soldier, clad in chlamys, with richly curled hair, and carrying with his left the surgeon's box which marks him as a medical saint, can be no other than this saint. Moreover, his costume, physognomy and attributes (scroll, surgeon's box) match closely those of the figure inscribed Panteleimon in John VII's frescoes in the Chapel of the Medical Saints; cf. Nordhagen 1968, 59-60, pls. 72 and 78. Dated around AD 650, this early Panteleimon gives weight to the assumption that the creation of an advanced gallery of individualized and clearly identifiable saints was a work that had started well before Iconoclasm, and thus was not merely an after-effect of it as several scholars have insisted; cf. Nordhagen 2005, 211-212.

${ }^{18}$ Eleousa: Nordhagen 1978, 130, Pl. 56.

${ }^{19}$ Deesis: Nordhagen 1978, 109-111, Pls. 30-31.

${ }^{20}$ Forty Martyrs of Sebasthe: Nordhagen 1978, 131-132, Pls. 57-59.

${ }^{21}$ Bertelli 1964.

22 Liber Pontificalis 1885, 1, 385. 


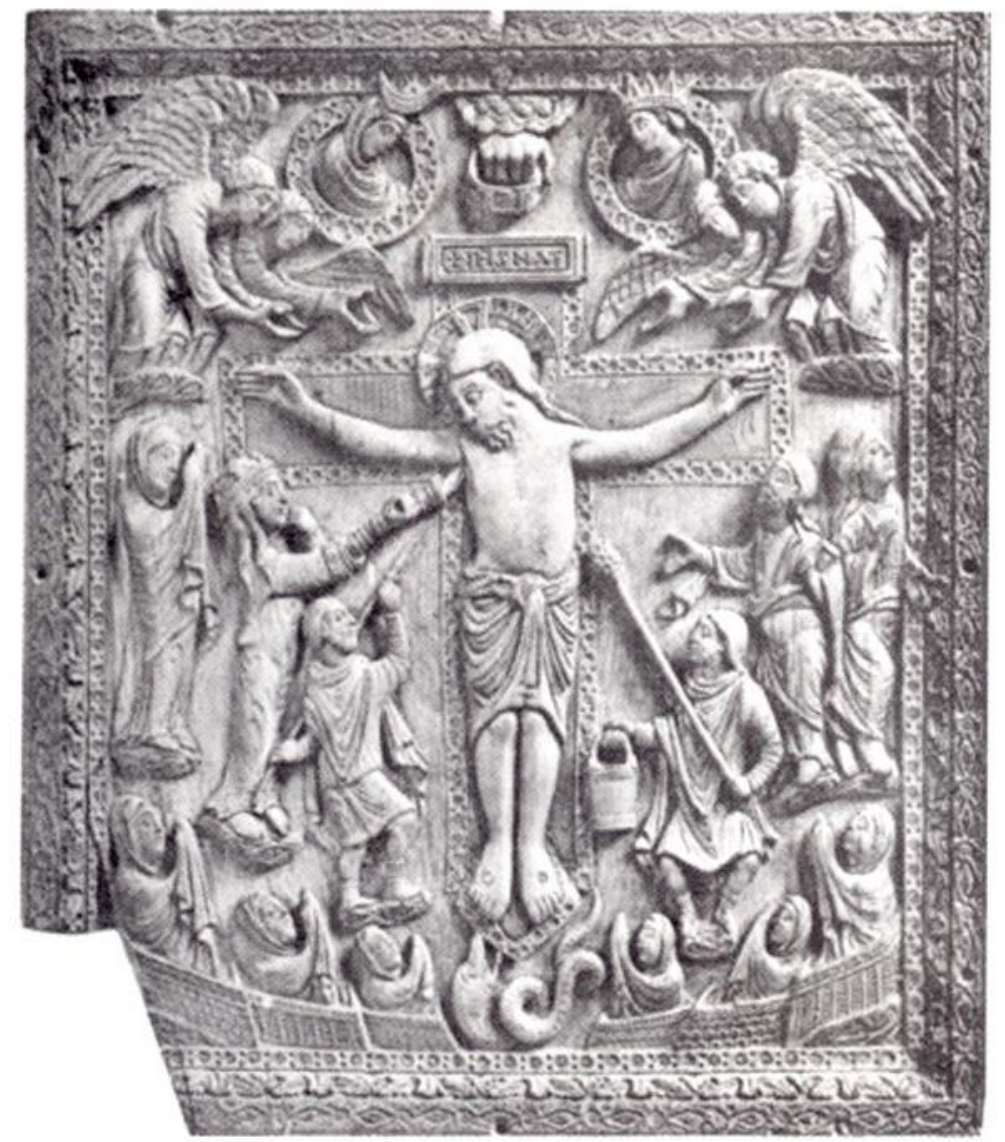

Fig. 4 Crucifixion with 'The Resurrection of the Dead', ivory plate. Tenth century. Florence, Museo Nazionale. Photo: from Goldschmidt, Elfenbeinskulpturen, Pl. 50, Fig. 114, 1914 (C). dominant scene of the Crucifixion on the main wall directly above it, and whose rare iconography it will have substantiated (see the Appendix, below). Anticipating the splendour of later Byzantine examples of such large pictorial schemes, the 'theatre of pictures' here reconstructed could rank as an extraordinary piece of iconographical craftmanship.

$$
\text { PJN }
$$

\section{Hypothesis B: the Anastasis elevated}

The task of deciphering the huge Crucifixion image in the presbytery of S. Maria Antiqua is hampered not only by the loss, suffered at the time

when the church lay in ruins, of a large part of its fresco surface, but also by the scarcity of comparable decoration schemes towards which to turn in search of parallel iconographic material. My note published in 2009 was an attempt to 'fill in' one of the crucial blank spaces in this composite image, the almost totally erased narrow zone which ran below the Crucifixion image on the presbytery main wall. ${ }^{23}$ The fragment left of this strip displays the background colours, green ground and a blue background, which are typical of the narrative panels in John VII's decoration; this may offer one of the clues as to what was once depicted here. The attempt to solve the Anastasis puzzle outlined above should start with some observations on the type of motif which originally may have had its place in this mysterious lower strip.

${ }^{23}$ Folgerø 2009, 207-219: 'the yellow slanted object' is documented in Folgerø 2009, 213, Figs. 5-8. 


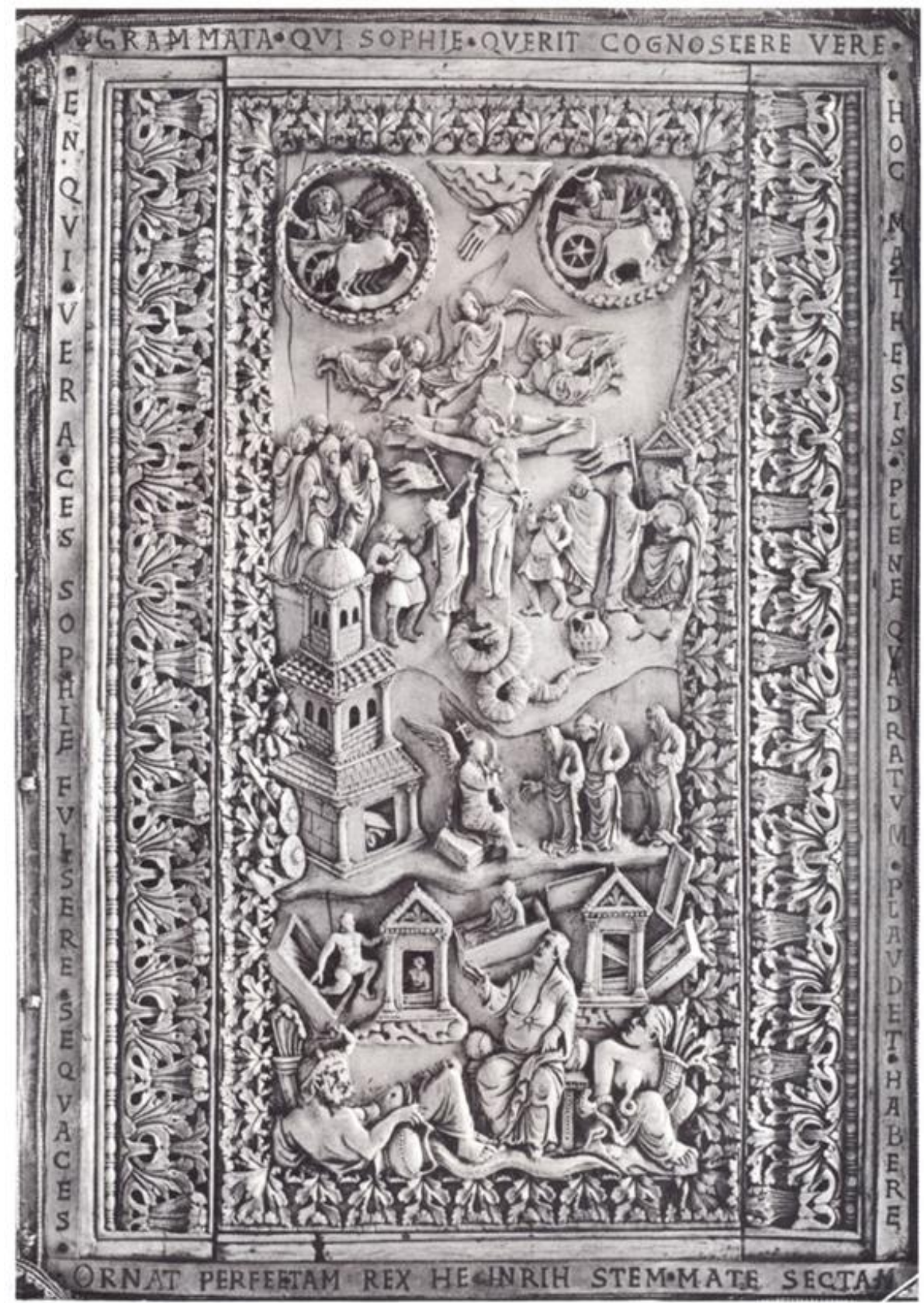

Fig. 5 Crucifixion with 'The Resurrection of the Dead', ivory cover-plate. AD 870. Pericopes of Henry II, Staatsbibliothek München. Photo: from Goldschmidt, Elfenbeinskulpturen, Pl. 20, Fig. 41, 1914 (C. 


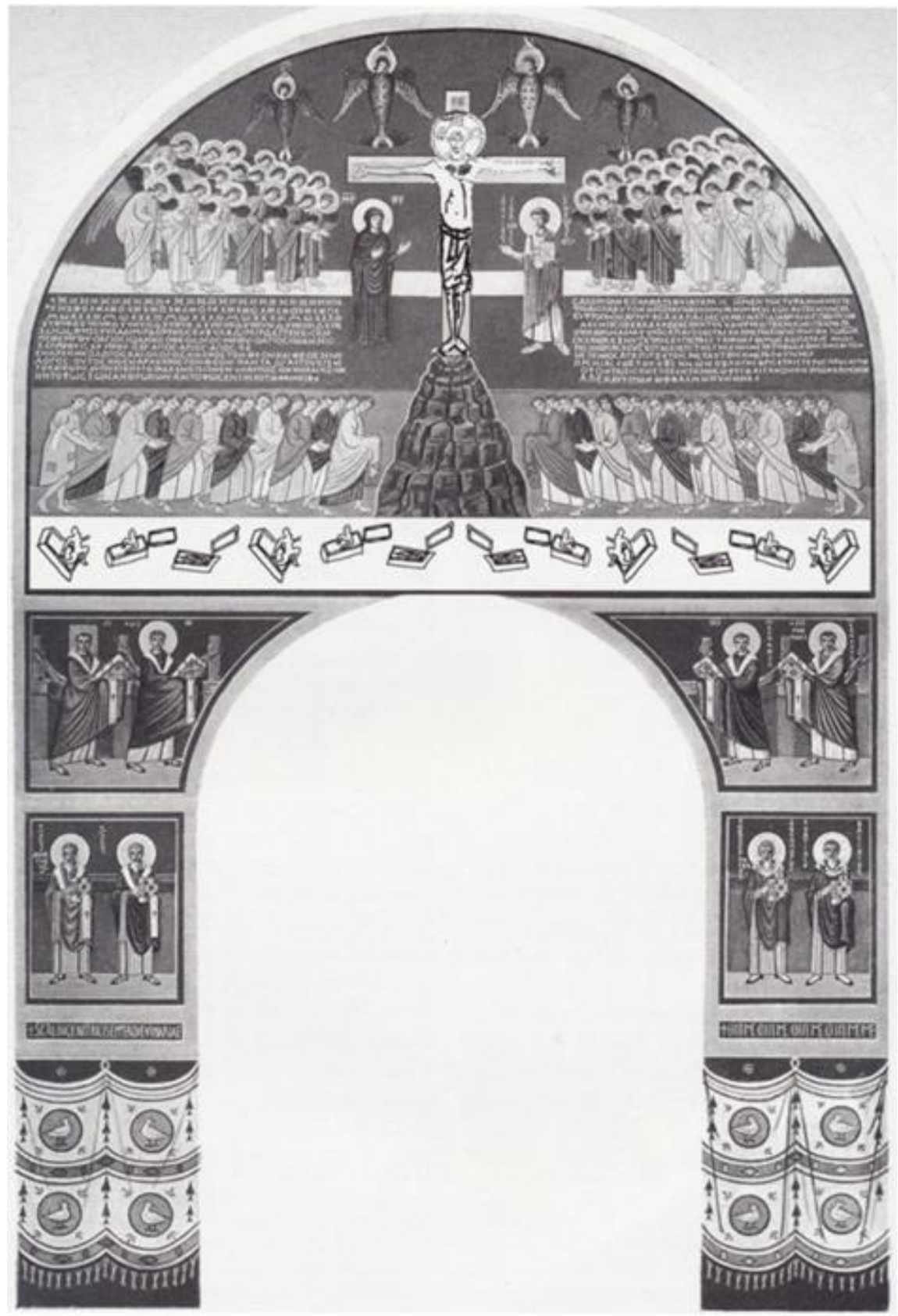

Fig. 6 'The Adoration of the Crucified', fresco on the presbytery triumphal arch in S. Maria Antiqua. Diagram by: Folgerø and Nordhagen based on the reconstruction by W. De Grüneisen (1911), with amendments concerning the figure of the Crucified Christ (centre) and the zone below the Cross ('The Resurrection of the Dead'). Photo: from Folgerø 2009 C). 
In the note from 2009 material was presented which supports the author's claim that 'the yellow slanted object' of which a fragnment is visible at the point where the zone is broken off, was part of either the corpus or the lid of a sarcophagus, and that the strip running under the Crucifixion had therefore held a scene with the Resurrection of the Saints ('The Dead Rising from their Graves'). ${ }^{24}$ Main arguments for this thesis are Carolingian and Ottonian crucifixion scenes in which the dead rise out of their tombs below the cross (Fig. 4). ${ }^{25}$ Most telling among these cases is the ivory cover-plate of the Pericopes of Henry II (AD 870), in which the ground below the cross is filled with large sarcophagi and their lids, with the dead emerging from them (Fig. 5). ${ }^{26}$ The scene on the pericope cover has served as the basis for the author's redrawn reconstruction of the presbytery Crucifixion image in its totality (Fig. $6) .^{27}$

Above, Nordhagen suggests that the evasive Anastasis may have had its place on an icon displayed on or near the altar of the church, a proposition fully acceptable yet based on the assumption that the scene had been 'lifted' from its context within the cycle of the Life of Christ and presented isolated from it, a procedure for which not many parallels can be found. The anomaly could be explained, however, by the significance ascribed to this theme, which led to it being given a place of prominence within the iconographic totality in the sanctuary. The present author will point to another possible solution to the question of where the curiously 'lost Anastasis' may have had its place. The thesis that a 'Resurrection of the Dead' was depicted in the lost lower zone of the Crucifixion image, will allow us to suggest, as one of several possibilities, that those who rose from their graves here were not the anonymous saints seen in the ivory works cited above, but rather figures taken directly out of the Anastasis image, Adam and Eve and the Old Testament kings, David and Solomon. This suggestion is based on the presence of a composition of exactly this type found on a Crucifixion ivory, plaque no. $\omega 26$ in the State Hermitage in St Petersburg (eleventh century) (Fig. 7) ${ }^{28}$ Here, Adam and Eve rise out of a sarcophagus to the left below the cross, and to the right, rising out of a similar tomb, are the Old Testament kings, David and Solomon, to form what could be termed a 'pared-down' or 'abridged' version of the Anastasis. Discussed by Kartsonis, a similar assimilation of the Anastasis protagonists into a Crucifixion scene may have been part of the (now lost) mosaic cycle of the Church at Pege dated around AD 870-879.29

The almost complete loss of intonaco in the lower zone of of the Crucifixion ('The Adoration of the Crucified') in S. Maria Antiqua bars us from knowing whether a full merger of the two motifs could possibly have been depicted here, with the Anastasis scene placed immediately below the cross on the cliff of Golgotha. Still, that the 'missing' Anastasis may have had its position in this area, is supported by the discovery of the depiction of the scene

${ }^{24}$ Folgerø 2009, Figs. 3-8.

25 Goldschmidt 1914, 114, Taf. 50.

26 Goldschmidt 1914, 41, Taf. 20.

${ }^{27}$ Folgerø 2009, Fig. 9.

28 Bank 1965, 356, Pl. 145.

${ }^{29}$ Kartsonis 1986, 146-150. 


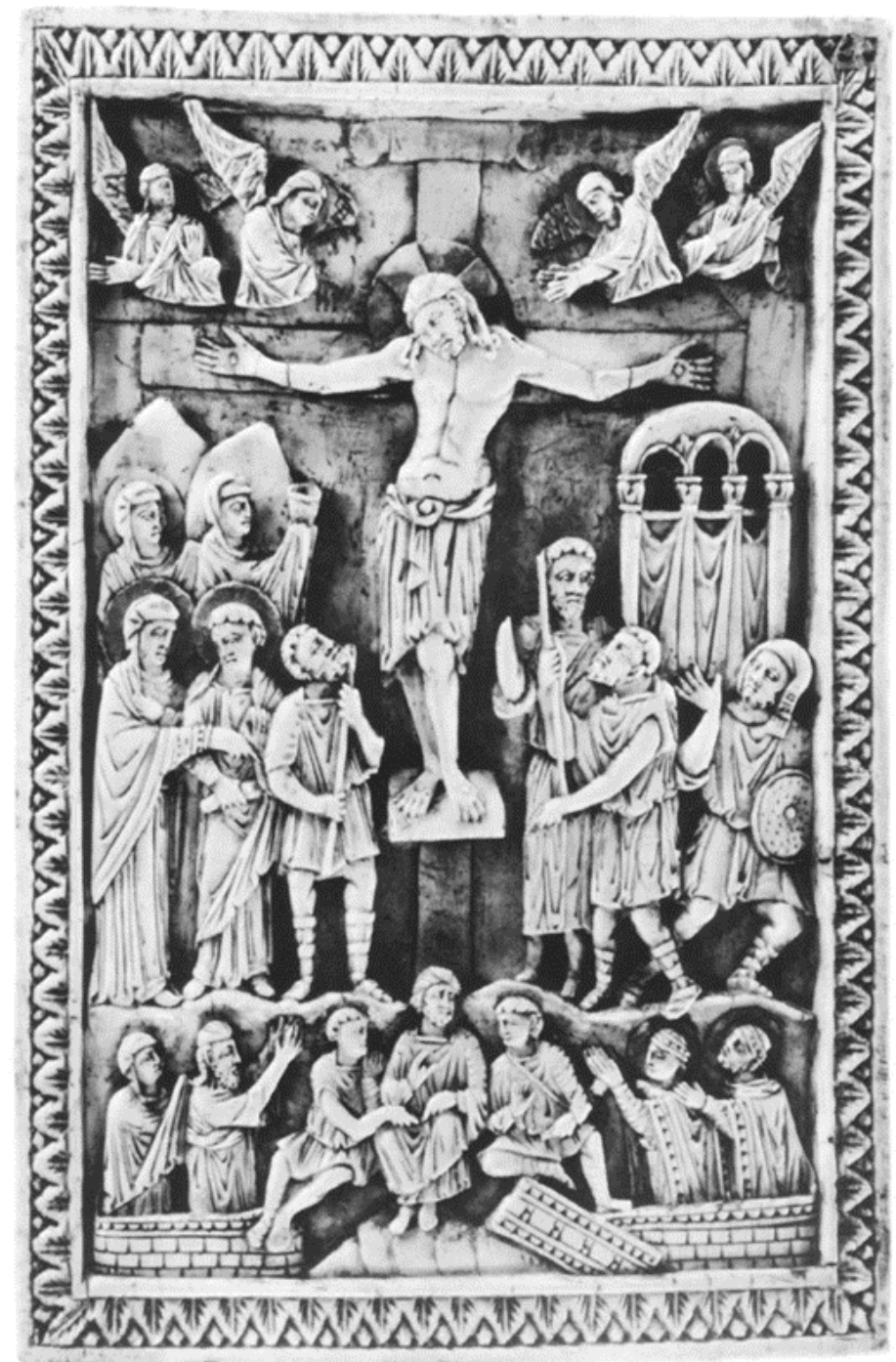

Fig. 7 Crucifixion with Adam and Eve and the Old Testament kings rising from sarcophagi below The Cross. Ivory plaque, eleventh century. State Hermitage, St Petersburg. Photo: from Bank, Pl. 145, 1965 (C). on a Byzantine ivory casket in the Württembergisches Landesmuseum in Stuttgart (Fig. 8). ${ }^{30}$

Here, 'The Resurrection of the Dead' appears together with an Anastasis of common matrix: Christ trampling on Hades and lifting a draped figure from a sarcophagus is surrounded to the left and right by more figures standing in or rising from sarcophagi, some of which are half-open, under heavy lids. The scene is an indication-never to be verified-that a similar composition once occupied the lowest sector of the vast Crucifixion picture in $\mathrm{S}$. Maria Antiqua. ${ }^{31}$ Thus the 'lost Anastasis' may have been dramatically present, centrally, in the ensemble on the arch, to the enhancement of its Christological tenor. It might be assumed, as yet another possibility, that the inscription in large letters, traces of which may be seen on the remaining fragment of the Golgotha cliff below the cross, was thematically related to the

\footnotetext{
${ }^{30}$ Kartsonis 1986, 159, Fig. 57. For the date of the ivory, see Goldschmidt and Weitzmann 1934, 2, n. 24b. In the St Petersburg plaque (Fig. 7) the figures of Adam and Eve and the Old Testament kings in their sarcophagi are not situated directly below the foot of the cross; here, another detail in the Biblical narrative of what took place at Golgotha is illustrated, the three soldiers who gamble on Christ's robe. Cf. an almost identical constellation with the three soldiers on a Byzantine ivory in the Metropolitan Museum of Art, NY; Frazer 1974, 153, Fig. 1.

31 On iconographical sceneries linking the Crucifixion and Anastasis see Kartsonis 1986, 159-160; cf. The Church at Pege (above) and n. 29.
} 


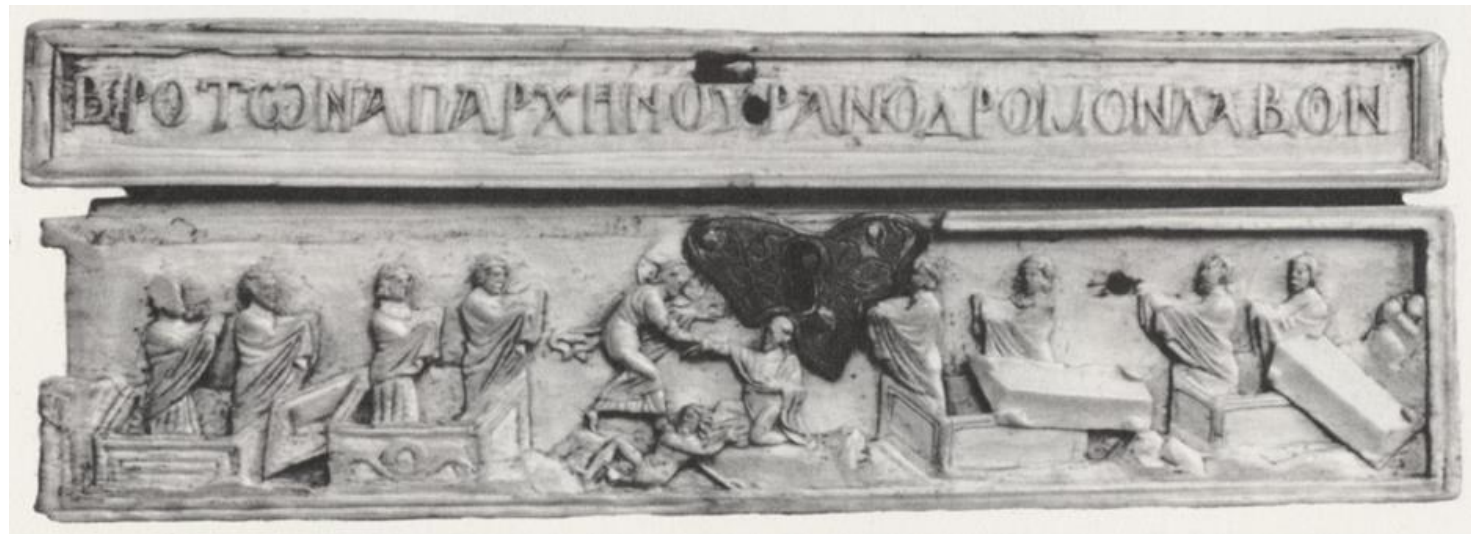

Fig. 8 The Anastasis and 'The Resurrection of the Dead' conjoined. Ivory casket, tenth century. Württembergisches Landesmuseum, Stuttgart. Photo: from Goldschmidt and Weitzmann, Byzantinische Elfenbeinskulpturen, Fig. 24b, 1934 C.

narrative in the lost zone. ${ }^{32}$ However, as there are only two, possibly three, letters remaining of it, it cannot be deciphered.

POF

\section{Appendix}

Image versus text: the Quinisext 82nd Canon and the question of the proper standin for the prohibited lamb symbol

Discussing the Quinisext 82nd Canon and how, in the coinage of Emperor Justinian II, this canon may have led to the creation of a new portrait type of Christ (Type B), James Breckenridge in 1959 turned to another of the widely debated questions connected with this famous edict. ${ }^{33}$ Decreed by the Quinisext Council at Constantinople in AD 692, the 82nd Canon advocated, in an unprecedented effort at iconographic reform, the abolishment of the Lamb symbol, a motif highly venerated in Early Christian art. The reasons for this major reversal are a matter of intense scholarly debate, a discussion which includes the equally pressing question as to what kind of imagery the Canon recommended as a proper substitute for the outlawed Lamb. Breckenridge challenges an authority of some stature when he claims:

This Canon (The 82nd) has nothing to do with the specific scene of The Crucifixion as such, and had no effect upon the artistic tradition of that scene, except in the general sense that it influenced all subsequent, Byzantine representations of Christ. ${ }^{34}$

\footnotetext{
32 Nordhagen 1968, 45, Pl. 114.

33 Breckenridge 1959, 83 n. 12, in the chapter 'The chronology of the coins of Justinian II' (78-90). The Quinisext Council and its effect on Justinian's monetary issues was discussed in Grabar 1957, 40-54.

34 Breckenridge1959, 83 n. 12.
} 
This statement sums up his critical appraisal of Dom Heféle's reading of the 82nd Canon; in his study from 1909, the French savant had suggested that the Canon was meant, expressly, to promote the scene of the Crucifixion as the legitimate replacement for the discredited Lamb. ${ }^{35}$ Breckenridge for his part argued that the prescript was of a more general kind, and that the Canon, without giving preference to any type of image in particular, 'bade that "Christ in human form" was to be set up instead of the Lamb'. According to Breckenridge, Heféle's comments were based on a misinterpretation caused by 'the defective text' in the original source, Gian Domenico Mansi's Sacrorum conciliorum nova et amplissima collectio. ${ }^{36}$ The problem regarding what the Canon actually sets down was thereby relegated to the arena of learned philological discourse. Further deliberations on the iconographical issues raised by it were supposed to take place within the restricted field of textual analysis, well beyond the reach of the ordinary motif historian.

It should be stressed, however, that in 1959, when Breckenridge advanced these thoughts, he was unaware of the campaign of research that was then going on in S. Maria Antiqua in the Roman Forum (1957-1960), and from which new material for insight into the matter was beginning to emerge. Nearly a decade elapsed before the results of this campaign were published by the present author; ${ }^{37}$ a major outcome of them was the corraboration they seemed to bring, on several points, of Heféle's hypothesis. One crucial observation regards the Crucifixion scene set up by John VII on the presbytery main wall: in it, The Crucified bears the coiffure and facial form of Breckenridge's singular Christ Type B known from Justinian II's late coinage (Figs. 9a-b). ${ }^{38}$ This feature with its imperial connotations cannot be but a mark of the importance ascribed to the statements broadcast by the imagery set up in the presbytery. ${ }^{39}$ The 'imperial stamp' imprinted upon this Crucifixion, in short, will seem to sustain my thesis (1968) that John's composition in its totality was a manifesto compounded to celebrate The 82nd Canon. Not only that; structured in the manner of a monumental 'Adoration of the Lamb', but having The Crucified instead of The Lamb placed at its centre, this large picture may give us the answer to the conundrum outlined above. The fresco with its unusual composition pronounces, irrefutably it will seem, that the Crucifixion and no other theme was to be the rightful substitute for the Lamb symbol. ${ }^{40}$ See, however, the alternative eschatological reading by Folgerø. $^{41}$

\footnotetext{
35 Heféle 1909, 573.

36 Mansi 1759, 9, Cols. 977-980.

37 Nordhagen 1968, 43-54.

38 Nordhagen 1968, 43-44, Pls. 52-55.

${ }^{39}$ Cf. also n. 37. Eva Tea, without recognizing the iconographic key theme in the presbytery

Crucifixion, was still the first to suggest that this image was a proclamation connected with the Decree of the Quinisext 82nd Canon of AD 692; Tea 1937, 66-69.

${ }^{40}$ Nordhagen 1967, 388-390; 1968, 53-54, 95-98.

${ }^{41}$ Folgerø 2012, 106-126.
} 

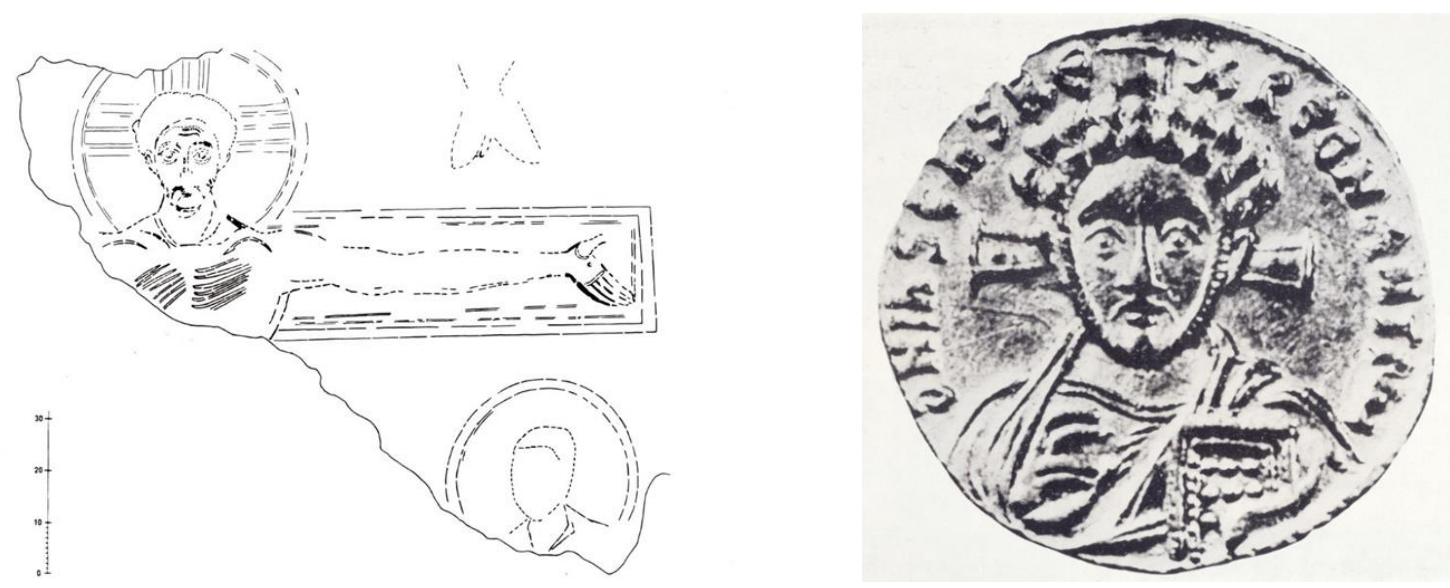

Fig. 9a (left) Crucified Christ from John VII's 'Adoration of the Crucified'. Triumphal arch in presbytery of S. Maria Antiqua (AD 705-707). Tracing: from Nordhagen, Pl.54, 1968 C. Fig. $9 b$ (right) Christ Type B (Breckenridge). Gold solidus from Justinian II's coin issue AD 705-711. Photo: from Breckenridge, Fig. 2, 7, 1957 (C).

It should be stated that Breckenridge later returned to the problem. In a note in the Byzantinische Zeitschrift from 1972 he endorsed the author's identification of the head of Christ in the Crucifixion fresco as a replica of the imperial Type B of Christ; further, he discussed what light this discovery might throw on the 82 nd Canon. ${ }^{42}$ Returning to Heféle's reading of 1909, he expressed what seems to be second thoughts regarding his 1959 stance on the matter.

Per Jonas Nordhagen

Professor emeritus, History of Art

The Department of Linguistic,

Literary and Aesthetic Studies

Univeristy of Bergen

pjnordhagen@gmail.com

Per Olav Folgerø

Associate Professor, History of Art

The Department of Linguistic,

Literary and Aesthetic Studies

Univeristy of Bergen

Per.Folgero@uib.no

42 Breckenridge 1972, 364-374. 


\section{Bibliography}

Ballardini, A. \& P. Pogliani. 2013: 'A Reconstruction of the Oratory of John VII (705707)', in R. McKitterick, J. Osborne, C.M. Richardson \& J. Story (ed.). Old St. Peter's Rome, Cambridge University Press: Cambridge, 190-213.

Bank, A. 1965: Byzantine Art in the Collections of the USSR, Sovietsky Khudozhnik: Leningrad \& Moscow:

Bertelli, C. 1964: La Madonna di S. Maria in Trastevere. Storia, iconografia, stile di un dipinto romano dell'ottavo secolo, Eliograf: Rome.

Breckenridge, J. 1959: The Numismatic Iconography of Justinian II (685-695, 705-711 A.D.), American numismatic society: New York.

Breckenridge, J. 1972: 'Evidence for the Nature of Relations between Pope John VII and the Byzantine Emperor Justinian II', BZ 65 (2): 364-374.

de Grüneisen, W. 1911: Sainte Marie Antique, vol. 1-2, L'Erma di Bretschneider: Rome.

Folgerø, P.O. 2009: 'The Lowest, Lost Zone in The Adoration of the Crucified scene in S. Maria Antiqua in Rome: A New Conjecture', JW arb 72: 207-219.

Folgerø, P.O. 2012: 'The Text-Catena in the Frescoes in the Sanctuary of S. Maria Antiqua in Rome (705-707 A.D.): An Index of Cultural Cross-Over in $7^{\text {th }}-8$ th Century Rome?', in H.V. Holm, S. Lægreid \& T. Skorgen (ed.). The Borders of Europe. Hegemony, Aesthetics and Border Poetics, Aarhus University Press: Aarhus, 106-126.

Goldschmidt, A. 1914: Die Elfenbeinskulpturen aus der Zeit der karolingischen und sächsischen Kaiser, VIII.-XI. Jabrbundert 1, Deutscher Verlag für Kunstwissenschaft: Berlin.

Frazer, M.E. 1974: 'Hades Stabbed by the Cross of Christ', Mus. J. 9: 153-161.

Goldschmidt, A. \& K. Weitzmann. 1934: Die byzantinischen Elfenbeinskulpturen des X.-XII. Jahrbundert 2, Deutscher Verlag für Kunstwissenschaft: Berlin.

Grabar, A [1936] 1971: L'empereur dans l'art byzantin. Recherches sur l'art officiel de l'empire d'Orient, Les Belles lettres: Paris.

Grabar, A. 1957: L'iconoclasme byzantin. Dossier archéologique, College de France: Paris. 
Grabar, A. 1980: 'Essai sur les plus anciennes representations de la Résurrection du Christ', MonPiot 63 (1): 105-141.

Heféle, K.J. 1909: Histoire des conciles daprès des documents originaux, Letouzey et Ané: Paris.

Kartsonis, A. 1986: Anastasis, The Making of an Image, Princeton University Press: Princeton.

Lazareff, V. 1967: Storia della pittura bizantina, G. Einaudi: Turin.

Le Liber Pontificalis: texte, introduction et commentaire, vol. 1, edited by L. Duchesne \& C. Vogel, E. Thorin: Paris, 1885.

Mansi, G.D. 1759: Sacrorum conciliorum nova et amplissima collectio, vol. 9, Zatta: Florence \& Venice.

Nordhagen, P.J. 1965: 'The Mosaics of John VII (705-707 A.D.). The Mosaic Fragments and their Technique', ActaIRN 4 (2): 121-193.

Nordhagen, P.J. 1967: 'John VII's adoration of the Cross in S. Maria Antiqua', JWarb 10: 388-390.

Nordhagen, P.J. 1968: The Frescoes of John VII (705-707 A.D.) in S. Maria Antiqua in Rome, L'Erma di Bretschneider, Rome.

Nordhagen, P.J. 1978: 'S. Maria Antiqua: The Frescoes of the Seventh Century', ActaIRN 4 (8): 21-89.

Nordhagen, P.J. 2017: 'The Frescoes of John VII (705-707 A.D.) in S. Maria Antiqua. Supplementum: The Painted Inscriptions', ActaIRN 29: 163-176.

Tea, E. 1937: La basilica di Santa Maria Antiqua, Vita e Pensiero: Milan.

Wilpert, J. 1917: Die römischen Mosaiken und Malereien der christlichen Bauten vom IV. bis XIII. Jabrbundert, Herder: Freiburg im Breisgau. 